\title{
The Interactive Web-Based Program MSmonitor for Self-Management and Multidisciplinary Care in Persons With Multiple Sclerosis: Quasi-Experimental Study of Short-Term Effects on Patient Empowerment
}

Peter Joseph Jongen ${ }^{1,2}$, PhD; Gezien ter Veen ${ }^{3,4}$, MNAP; Wim Lemmens ${ }^{5}$; Rogier Donders ${ }^{5}, \mathrm{PhD}$; Esther van Noort ${ }^{6}$, MSc; Esther Zeinstra ${ }^{4}, \mathrm{PhD}$

${ }^{1}$ Department of Community and Occupational Medicine, University Medical Centre Groningen, University of Groningen, Groningen, Netherlands

${ }^{2}$ MS4 Research Institute, Nijmegen, Netherlands

${ }^{3}$ Zorggroep Noorderboog, Meppel, Netherlands

${ }^{4}$ Isala Hospital, Meppel, Netherlands

${ }^{5}$ Radboud University Medical Center, Department for Health Evidence, Nijmegen, Netherlands

${ }^{6}$ Curavista bv, Geertruidenberg, Netherlands

Corresponding Author:

Peter Joseph Jongen, PhD

MS4 Research Institute

Ubbergseweg 34

Nijmegen, $6522 \mathrm{KJ}$

Netherlands

Phone: 31243239146

Email: ms4ri@kpnmail.nl

\section{Abstract}

Background: Empowerment helps persons with a chronic disease to self-manage their condition and increase their autonomy and participation. MSmonitor (Curavista bv) is an interactive Web-based program for self-management and multidisciplinary care in multiple sclerosis (MS). It includes, among others, short questionnaires on fatigue (Modified Fatigue Impact Scale-5 [MFIS-5]) and health-related quality of life (HRQoL, Leeds Multiple Sclerosis Quality of Life [LMSQoL]); long questionnaires on disabilities, perception of disabilities (Multiple Sclerosis Impact Profile), and HRQoL (Multiple Sclerosis Quality of Life-54); a Medication and Adherence Inventory and an Activity Diary. The combination MFIS-5, LMSQoL, and Medication and Adherence Inventory constitutes the Quick Scan.

Objective: This study aimed to investigate the short-term effects of MSmonitor on empowerment in patients with MS.

Methods: We conducted a quasi-experimental study in a general hospital. Of the 180 patients with MS, 125 were eligible, 30 used MSmonitor, and 21 participated in the study (mean age 45.4 years, SD 10.2 years). A total of 24 eligible patients who did not use MSmonitor constituted the control group (mean age 49.3 years, SD 11.4 years). At baseline and at 4 months, we assessed self-efficacy (Multiple Sclerosis Self-Efficacy Scale [MSSES]), participation and autonomy (Impact on Participation and Autonomy [IPA] questionnaire), and self-management (Partners In Health [PIH] questionnaire). Differences between time points and groups were tested with paired $t$ tests and $\chi^{2}$ tests.

Results: In the MSmonitor group, follow-up values remained unchanged for MSSES control $(P=.19)$, MSSES function $(P=.62)$, IPA limitations $(P=.26)$, IPA problems $(P=.40)$, PIH recognition and management of symptoms $(P=.52)$, PIH adherence to treatment $(P=.80)$, and PIH coping $(P=.73)$, whereas the PIH knowledge score had improved (mean 27.8, SD 1.7 vs mean 28.7, SD $2.0 ; P=.02)$. The overall utilization rate of the program components was $83 \%$ and that of the Quick Scan was $95 \%$. In the control group, all outcomes had remained unchanged.

Conclusions: The results suggest that for first-time users of the MSmonitor program and their health care providers, it may not be justified to expect a short-term improvement in empowerment in terms of self-efficacy, self-management, autonomy, or participation. Furthermore, a lack of effect on empowerment is not because of nonusage of the program components. 
(J Med Internet Res 2020;22(3):e14297) doi: 10.2196/14297

\section{KEYWORDS}

multiple sclerosis; empowerment; self-management; eHealth; internet-based intervention; internet-based communication; personal autonomy; social participation; self-efficacy

\section{Introduction}

\section{Background}

\section{Multiple Sclerosis}

Multiple sclerosis (MS) is a chronic inflammatory and degenerative disease of the central nervous system (CNS). It is the most frequent chronic CNS disease in young adulthood, and the majority of patients experience their first symptoms at the age of 20 to 40 years [1]. Intermittent or continuous disease activity results in a stepwise or slow increase in disabilities over time [1]. The disease course is largely unpredictable, as is the response to disease-modifying drug (DMD) treatment [1,2]. MS is incurable, as the effectiveness of DMD treatment is only partial and limited to the inflammatory component of the disease $[1,2]$.

\section{Patient Empowerment and Web-Based Health Services}

Persons with chronic conditions such as MS depend on their own insights to manage daily activities and self-care. To make optimal choices, to evaluate the effects of their choices, and to also contribute to a preventive, personalized, and participatory health care, it is paramount for them to be empowered [3]. Empowerment has been defined as a process: the mechanisms by which people, organizations and communities gain mastery over their lives [4]. Thus, patient empowerment may be defined as the process by which patients discover and develop the inherent capacity to be responsible for one's own life $[5,6]$. Although the concept of patient empowerment is still developing [6,7], empowered patients are generally considered to control their situation, have a critical attitude, and participate and perform tasks in an encouraging environment $[3,8,9]$. A recent systematic literature review of qualitative studies identified control, coping, knowledge, participation, support, and legitimacy as key aspects of patient empowerment [6]. Notably, interventions that aimed at improving patient empowerment have resulted in higher self-efficacy and self-care competence [10].

Web-based health services use telecommunications and information technology to provide care, education, and monitoring services to patients [11]. In patients with MS, Web-based health services have been shown to result in improved health care because of improved symptom management and treatment adherence [12-15]. E-communication can be defined as communication via Web-based platforms or apps [16-18], and among MS patients, e-communication has high levels of acceptance for exchanging information with health care providers [19]. Information systems with an e-communication function have also been found to be useful in enhancing interdisciplinary communication [20,21]. Consequently, it has been suggested that e-communication should be integrated into electronic health services for patients with MS [19].

\section{MSmonitor}

Against this background, we developed MSmonitor, an interactive Web-based program for self-management and multidisciplinary care in persons with MS, that can be used on computers, tablets, and smart phones [22-24]. At the time of the study, MSmonitor included short questionnaires on fatigue (Modified Fatigue Impact Scale-5 [MFIS-5]) [25,26], health-related quality of life (HRQoL, Leeds Multiple Sclerosis Quality of Life [LMSQoL] questionnaire) [27,28], and anxiety and depression (Hospital Anxiety and Depression Scale [HADS]) [29-31]; long questionnaires on disabilities and perception of disabilities (Multiple Sclerosis Impact Profile [MSIP]) [32,33] and HRQoL (Multiple Sclerosis Quality of Life-54 [MSQoL-54] questionnaire) [34]; inventories (Medication and Adherence Inventory, Miction Inventory); and diaries (Activity Diary, Miction Diary) [22-24]. We previously reported that patients who used the combined MFIS-5 and LMSQoL questionnaires at least twice in a period of up to 6 months showed an improved HRQoL and that in these patients, the degree of fatigue improvement correlated with the frequency of Activity Diary usage [24].

Conceivably, MSmonitor usage may lead in various ways to an improvement of empowerment. For example, the Activity Diary and MFIS-5 give insight into factors affecting fatigue and thus facilitate self-management of fatigue and fatigue-related symptoms. The quantified overview of (perceived) disabilities given by the MSIP informs patients about the relative importance of their symptoms and thus facilitates focused self-management. Documentation of missed doses in the Medication and Adherence Inventory may help improve adherence to DMD treatment.

While developing MSmonitor, we did not intend the program to generate short-term effects, as MS is a progressive disease that most patients are afflicted with for decades. However, as we live in an instant gratification era, where everything seems to be available immediately via smart phone or the internet $[35,36]$, we became aware that patients might indeed expect early results. Therefore, to obtain knowledge about the short-term effect of MSmonitor on patient empowerment, we conducted a quasi-experimental study.

\section{Objective}

The aim of the study was to explore short-term changes in empowerment in persons with MS using MSmonitor.

\section{Methods}

\section{MSmonitor}

MSmonitor is used by about 1500 patients and their health care providers in 23 hospitals in the Netherlands. 


\section{Concept}

The concept is based on the autonomy of patients, the multidisciplinary character of MS care, and the collaboration between stakeholders involved in MS care [23,24]. The program was developed gradually by the immaterial and material input of various stakeholders [22-24]. By facilitating self-assessments and self-management, MSmonitor aims to use and increase patients' autonomy. Patients own their personal data generated by the program and decide which health care providers can have access to their data [23,24]. By making self-assessment outcomes available to the multidisciplinary team, MSmonitor helps patients in preventing unnecessary measurements and promotes the use of patient-reported outcomes [23,24].

\section{Content}

At the time of the study, the content comprised 9 components in 3 categories: psychometrically validated questionnaires, inventories, and diaries. The characteristics and availability of the various components are presented in Table 1.

Alerts are sent when questionnaires are available, and reminders are sent when scheduled questionnaires are not completed. For all questionnaires, scores are automatically generated and presented in graphs and tables to patients and authorized caregivers (Figure 1), as well as changes over time (Figure 2).

Table 1. Characteristics and availability of MSmonitor components.

\begin{tabular}{|c|c|c|c|c|c|}
\hline Name & Purpose & Structure & $\operatorname{Min}^{a}-\max ^{\mathrm{b}}$ & Validation & Availability \\
\hline $\begin{array}{l}\text { MFIS-5 }{ }^{\mathrm{c}} \text { question- } \\
\text { naire }\end{array}$ & $\begin{array}{l}\text { Perceived impact of fatigue on } \\
\text { daily activities over past month }\end{array}$ & 5 items $(0-4)$ & 0-20 (lower=better) & $\begin{array}{l}\text { Fisk et al [25]; } \text { NMSS }^{\mathrm{d}} \\
\text { [26] }\end{array}$ & Monthly \\
\hline $\begin{array}{l}\text { LMSQoL }^{\mathrm{e}} \text { ques- } \\
\text { tionnaire }\end{array}$ & $\begin{array}{l}\mathrm{MS}^{\mathrm{f}} \text {-related aspects of } \mathrm{QoL}^{\mathrm{g}} \text { over } \\
\text { past month }\end{array}$ & 8 items $(0-3)$ & $0-24$ (higher=better) & $\begin{array}{l}\text { Ford et al [27]; Ensari et al } \\
{[28]}\end{array}$ & Monthly \\
\hline $\begin{array}{l}\text { MSIP } \\
\text { naire }\end{array}$ & $\begin{array}{l}\text { Overview of actual MS-related } \\
\text { disabilities (a) and perception of } \\
\text { disabilities (b) }\end{array}$ & $\begin{array}{l}36 \text { a-items; } 36 \text { b- } \\
\text { items; scorings } \\
\text { variable }\end{array}$ & $\begin{array}{l}7 \text { domain and } 4 \text { symp- } \\
\text { tom scores, } 0 \text {-variable } \\
\text { (lower=better) }\end{array}$ & $\begin{array}{l}\text { Wynia et al [32]; Wynia et } \\
\text { al [33] }\end{array}$ & 6 monthly \\
\hline $\begin{array}{l}\text { MSQoL }{ }^{\mathrm{i}}-54 \text { ques- } \\
\text { tionnaire }\end{array}$ & $\begin{array}{l}\text { Multidimensional assessment of } \\
\text { physical and mental MS-related } \\
\text { QoL over } 4 \text { weeks }\end{array}$ & $\begin{array}{l}54 \text { items, various } \\
\text { scorings }\end{array}$ & $\begin{array}{l}\text { Physical QoL, 0-100; } \\
\text { mental QoL, 0-100 } \\
\text { (higher=better) }\end{array}$ & Vickrey et al [34] & Yearly \\
\hline $\begin{array}{l}\text { HADS }^{\mathrm{j}} \text { question- } \\
\text { naire }\end{array}$ & $\begin{array}{l}\text { Anxiety in past week; depression } \\
\text { in past week }\end{array}$ & $\begin{array}{l}7 \text { items }(0-3) ; 7 \\
\text { items }(0-3)\end{array}$ & $\begin{array}{l}0-21 \text { (lower=better); 0- } \\
21 \text { (lower=better) }\end{array}$ & $\begin{array}{l}\text { Honarmand and Feinstein } \\
\text { [30]; Watson et al [31] }\end{array}$ & On indication \\
\hline $\begin{array}{l}\text { Medication and } \\
\text { Adherence Invento- } \\
\text { ry }\end{array}$ & $\begin{array}{l}\text { Medication and } \mathrm{DMD}^{\mathrm{k}} \text { adherence } \\
\text { in past month }\end{array}$ & N/A ${ }^{1}$ & $\mathrm{~N} / \mathrm{A}$ & N/A & Monthly \\
\hline Miction Inventory & Actual urological symptoms & N/A & N/A & N/A & On indication \\
\hline Activity Diary & $\begin{array}{l}\text { Activities and rest periods in } 24 \\
\text { hours }\end{array}$ & $\mathrm{N} / \mathrm{A}$ & $\mathrm{N} / \mathrm{A}$ & N/A & Daily \\
\hline Miction Diary & $\begin{array}{l}\text { Frequency and quantity of miction } \\
\text { and fluid intake in } 24 \text { hours }\end{array}$ & $\mathrm{N} / \mathrm{A}$ & N/A & $\mathrm{N} / \mathrm{A}$ & On indication \\
\hline
\end{tabular}

\footnotetext{
${ }^{\mathrm{a}}$ Min: minimum score.

${ }^{\mathrm{b}}$ Max: maximum score.

${ }^{\mathrm{c}}$ MFIS-5: Modified Fatigue Impact Scale-5 items.

${ }^{d}$ NMSS: National Multiple Sclerosis Society.

e LMSQoL: Leeds Multiple Sclerosis Quality of Life.

${ }^{\mathrm{f}} \mathrm{MS}$ : multiple sclerosis.

${ }^{\mathrm{g}} \mathrm{QoL}$ : quality of life.

${ }^{\mathrm{h}}$ MSIP: Multiple Sclerosis Impact Profile.

${ }^{\mathrm{i}}$ MSQoL-54: Multiple Sclerosis Quality of Life-54 items.

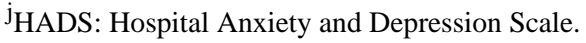

${ }^{k}$ DMD: disease-modifying drug.

${ }^{1}$ Not applicable.
} 
Figure 1. Screenshot of graphic presentation of Multiple Sclerosis Impact Profile (MSIP) disability scores in the domains muscle and movement, excretion and reproductive functions, mental functions, basic movement activities, activities of daily living, environmental factors, participation in life situations, and the symptoms fatigue, pain, speech, and vision (lower numbers). Upper numbers represent the maximum of the score range. Higher scores indicate a worse condition. Right bars give the actual score, left bars the previous score.

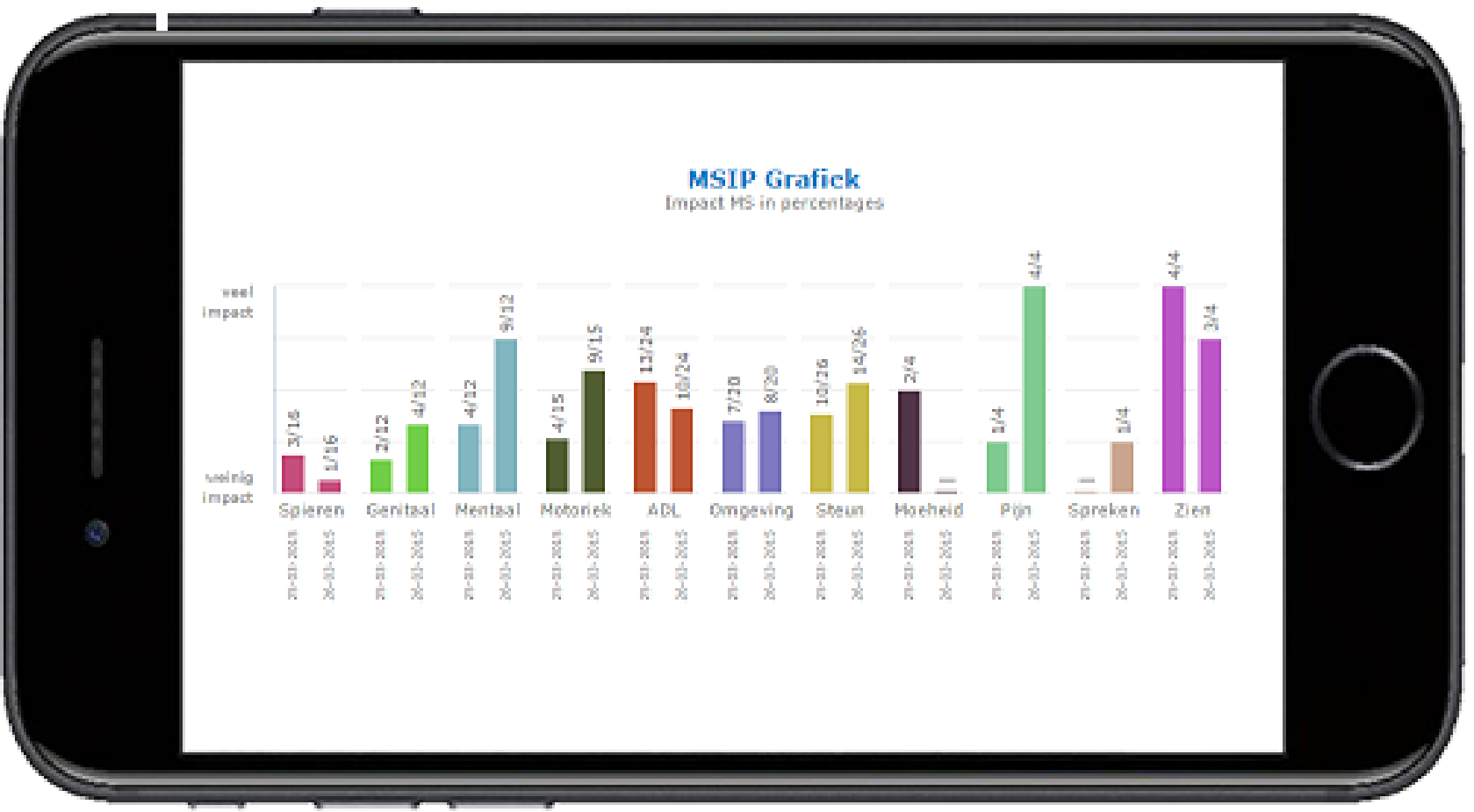

Figure 2. Screenshot of graphic presentation of changes over time in MFIS-5 and LMSQoL scores. The MFIS-5 score (higher is worse) is converted into a fitness (fitheid) score (higher is better) to match the direction of the LMSQoL score. Scores are converted into percentages (0\%, minimum score; 100\%, maximum score). MFIS-5: Modified Fatigue Impact Scale-5 items; LMSQoL: Leeds Multiple Sclerosis Quality of Life.

\section{Fitheid en kwaliteit van leven}

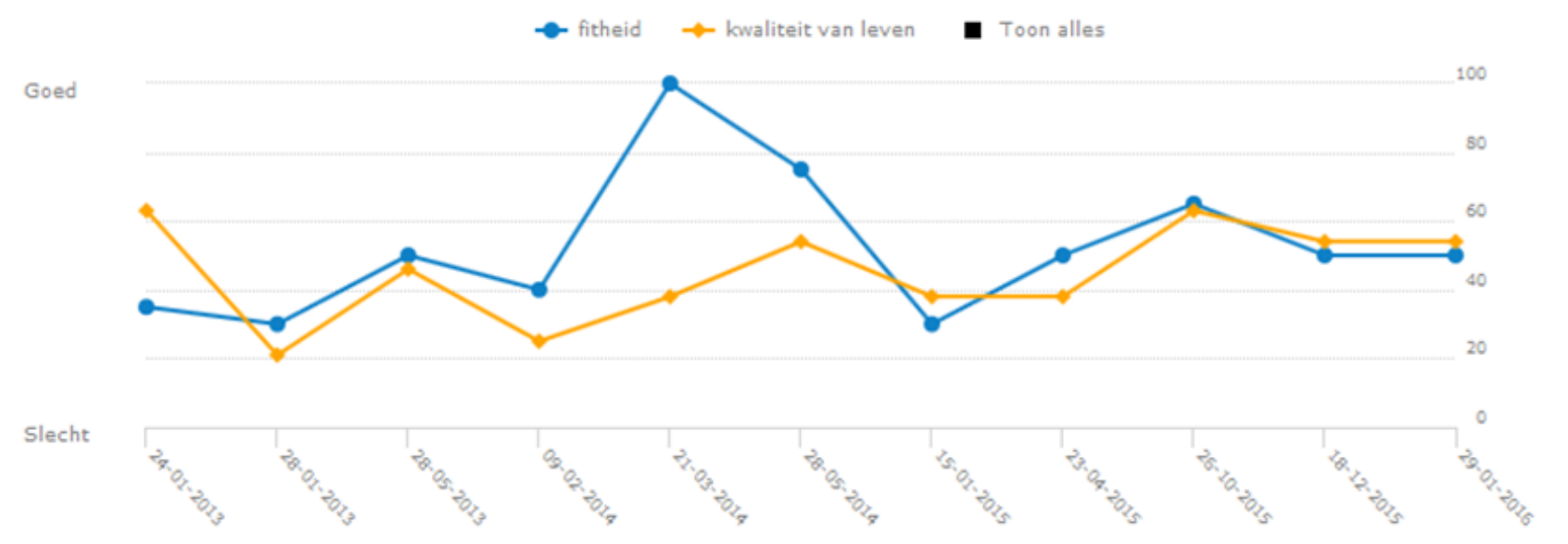

Inventories provide overviews and do not generate scores; for example, the Medication and Adherence Inventory gives an update of medication that is taken, the number of missed DMD doses in the last month, and the date and reason of eventual DMD treatment discontinuation. Diaries enable the recording of specific activities or functions and thus give insight into MS-related processes over 24-hour periods [23,24]. The Activity Diary records type and duration of activities and rest periods, whereas the Miction Diary documents the frequencies and quantities of mictions and fluid intakes [23,24]. The combined use of MFIS-5, LMSQoL, and Medication and Adherence Inventory (Quick Scan) enables quick self-assessments of fatigue, HRQoL, and adherence to DMD treatment. The HADS, Miction Diary, and Miction Inventory are only available to patients after indication by health care professionals and were therefore not part of the study.

\section{Study Design}

This was a prospective, quasi-experimental study. For the MSmonitor group, the baseline assessment was conducted when the participant was registered as a user. In all participants, follow-up assessment was conducted at 4 months. This follow-up period was chosen pragmatically and was dictated by the principal researcher's availability. We considered this 
period justifiable, as in chronic disorders, a follow-up at 3 to 6 months is generally qualified as short-term.

Owing to the study's time frame and the standard 6-month interval between consecutive completions of the MSIP and the MSQoL-54 (Table 1), the usage of these questionnaires was limited to single completions. Notably, to prevent patients from being overburdened, the program makes the MSQoL-54 available 3 months after the MSIP. Hence, 4 components were available for multiple use: the MFIS-5, LMSQoL and Medication and Adherence Inventory (Quick Scan), and the Activity Diary.

\section{Study Setting}

The study was performed in the Neurological Department of the Isala Diaconessenhuis, Meppel, the Netherlands. The Isala Diaconessenhuis is a medium-sized (120 beds) general hospital with 1300 neurological outpatient visits per year, 5000 of which being new referrals.

Figure 3. Study Flow Chart.

\section{Recruitment}

All patients registered with the diagnosis of MS constituted the study population ( $n=180$; Figure 3 ).

The exclusion criteria for participation were as follows: diagnosis of clinically isolated syndrome, actual medical doubts about MS diagnosis, serious cognitive impairment, limited knowledge of the Dutch language, and nursing home residents. As a result, 55 patients were not eligible. The remaining 125 eligible patients were invited for a general meeting to be informed about MSmonitor and the study, and patients who had not attended the meeting were informed by phone. A total of 30 patients decided to start with the program and 21 of these were willing to participate in the study. Of the 95 patients who decided not to start with the program, 75 were willing to participate in the study, and out of those, 24 consecutive persons were recruited to form the control group. So, it was actually the patients who decided which study group to join (MSmonitor or control), and this fact explains the quasi-experimental design of the study.

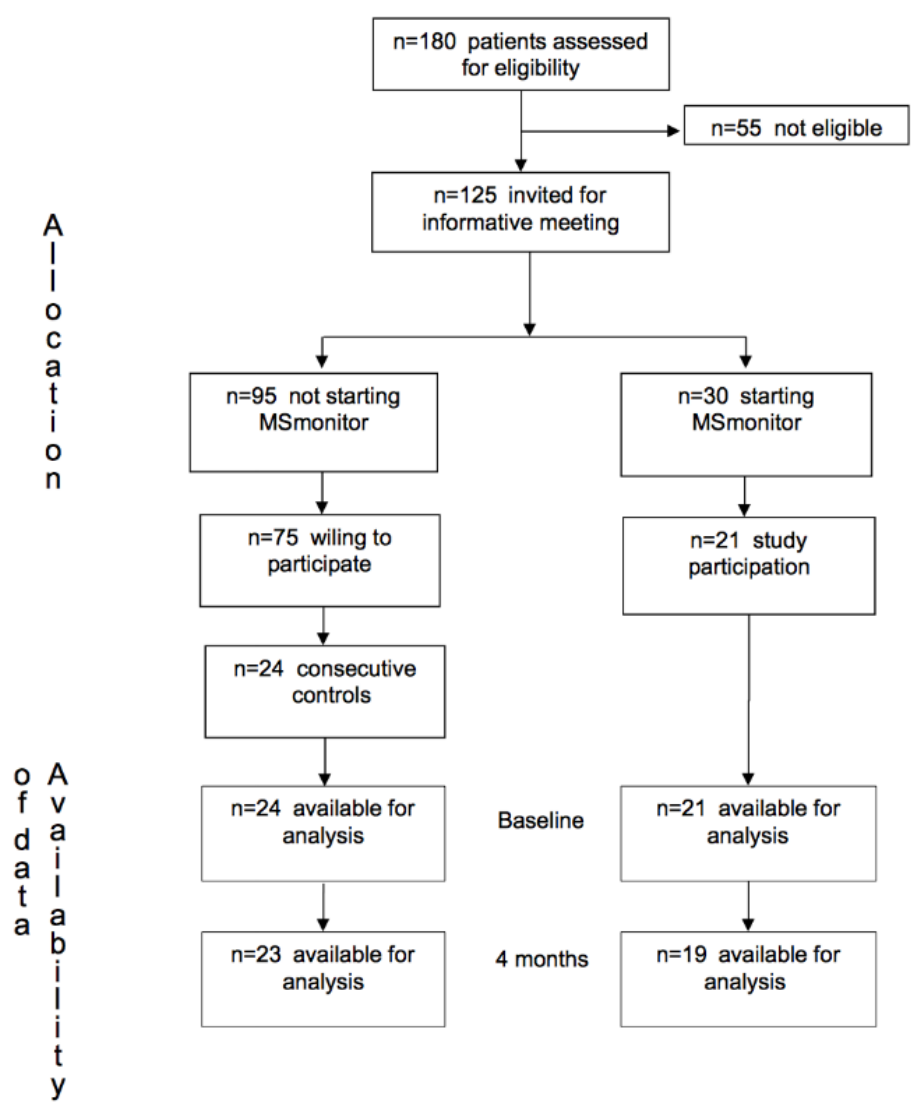

\section{Ethical Approval and Informed Consent}

The study did not qualify for being reviewed according to the Dutch Medical Research Involving Human Subjects Act of 1999. The study was carried out in compliance with the Declaration of Helsinki (Ethical Principles for Medical Research Involving Human Subjects version 2013; 64th World Medical Association General Assembly, Fortaleza, Brazil, October 2013) and the Dutch Medical Research Involving Human Subjects Act of 1999. Patients received no financial incentive or reward

to participate. The study was approved by the hospital's coordinator of local evaluation of medical experiments. Patients who agreed to participate signed an informed consent form.

\section{Data Collection}

Patient-reported data were obtained by the use of paper-and-pencil questionnaires sent by regular mail, 1 week before the start of study participation and at follow-up. The questionnaires were accompanied by a stamped return envelope addressed to the neurological outpatient department for the 
attention of the principal researcher. Owing to financial restrictions, it was not feasible to provide e-versions of the questionnaires and to integrate these into the program. Data on MSmonitor utilization were provided by Curavista bv, Geertruidenberg, the Netherlands.
The following aspects of empowerment were assessed using psychometrically validated questionnaires: self-efficacy, participation, autonomy, and self-management (Table 2). We did not use a general or disease-specific empowerment measure, as such measures were not available in Dutch.

Table 2. Questionnaires used to assess aspects of empowerment.

\begin{tabular}{|c|c|c|c|c|}
\hline Name & Purpose & Structure & $\operatorname{Min}^{\mathrm{a}}-\max ^{\mathrm{b}}$ & Validation \\
\hline MSSES $^{\mathrm{c}}$ control & $\begin{array}{l}\text { Confidence with managing symptoms and } \\
\text { coping with demands of illness }\end{array}$ & 9 items $(10-100)$ & $\begin{array}{l}90-900 \text { (higher }=\text { more } \\
\text { confidence) }\end{array}$ & Schwartz et al [37] $\left(\mathrm{MS}^{\mathrm{d}}\right)$ \\
\hline MSSES function & $\begin{array}{l}\text { Confidence with regard to functional abili- } \\
\text { ties }\end{array}$ & 9 items $(10-100)$ & $\begin{array}{l}90-900 \text { (higher }=\text { more } \\
\text { confidence) }\end{array}$ & Schwartz et al [37] (MS) \\
\hline $\mathrm{IPA}^{\mathrm{e}}$ limitations & Limitations to participation and autonomy & 32 items $(0-4)$ & $\begin{array}{l}0-128 \text { (lower=less limita- } \\
\text { tions) }\end{array}$ & $\begin{array}{l}\text { Vazirinejad et al [38] (MS); } \\
\text { Karhula et al [39] (MS) }\end{array}$ \\
\hline IPA problems & $\begin{array}{l}\text { Problems with limitations to participation } \\
\text { and autonomy }\end{array}$ & 9 items $(0-2)$ & $\begin{array}{l}0-18 \text { (lower=less prob- } \\
\text { lems) }\end{array}$ & $\begin{array}{l}\text { Vazirinejad et al [38] (MS); } \\
\text { Karhula et al [39] (MS) }\end{array}$ \\
\hline $\mathrm{PIH}^{\mathrm{f}}$ coping & Coping & 3 items $(0-8)$ & $\begin{array}{l}0-24 \text { (lower=better cop- } \\
\text { ing) }\end{array}$ & $\begin{array}{l}\text { Petkov et al [40] (CCC })^{\mathrm{g}} \text {; } \\
\left.\text { Lenferink et al [41] (COPD }{ }^{\mathrm{h}}\right)\end{array}$ \\
\hline PIH symptoms & Recognition and management of symptoms & 3 items $(0-8)$ & $\begin{array}{l}0-24 \text { (lower=better man- } \\
\text { agement of symptoms) }\end{array}$ & $\begin{array}{l}\text { Petkov et al [40] (CCC); Lenferink } \\
\text { et al [41] (COPD) }\end{array}$ \\
\hline PIH adherence & Adherence to treatment & 2 items $(0-8)$ & $\begin{array}{l}0-16 \text { (lower=better adher- } \\
\text { ence to treatment) }\end{array}$ & $\begin{array}{l}\text { Petkov et al [40] (CCC); Lenferink } \\
\text { et al [41] (COPD) }\end{array}$ \\
\hline PIH knowledge & Knowledge & 4 items $(0-8)$ & $\begin{array}{l}0-32 \text { (lower=better } \\
\text { knowledge) }\end{array}$ & $\begin{array}{l}\text { Petkov et al [40] (CCC); Lenferink } \\
\text { et al [41] (COPD) }\end{array}$ \\
\hline
\end{tabular}

${ }^{\mathrm{a}}$ Min: minimum score.

${ }^{\mathrm{b}}$ Max: maximum score.

${ }^{c}$ MSSES: Multiple Sclerosis Self-Efficacy Scale.

${ }^{\mathrm{d}} \mathrm{MS}$ : multiple sclerosis.

IPA: Impact on Participation and Autonomy.

${ }^{\mathrm{f}} \mathrm{PIH}$ : Partners In Health.

${ }^{\mathrm{g}} \mathrm{CCC}$ : comorbid chronic conditions not including MS.

${ }^{\mathrm{h}}$ COPD: chronic obstructive pulmonary disease.

Self-efficacy was assessed by the Multiple Sclerosis Self-Efficacy Scale (MSSES) [37], participation and autonomy were assessed by the Impact on Participation and Autonomy (IPA) questionnaire [38,39,42-44], and self-management behaviors and knowledge were assessed by the revised 12-item Partners In Health (PIH) scale [40,41].
At baseline, the level of education, degree of computer use, and degree of computer skills were assessed via multiple-choice questions (Table 3), as these factors may conceivably influence the speed with which persons become familiar with Web-based programs. 
Table 3. Demographics, disease characteristics, level of education, degree of computer use, and degree of computer skills in the MSmonitor group and the control group.

\begin{tabular}{|c|c|c|c|}
\hline Patient characteristics & MSmonitor $(\mathrm{n}=21)$ & Control $(n=24)$ & $P$ value \\
\hline Female, n (\%) & $17(81)$ & $17(71)$ & .43 \\
\hline Age (years), mean (SD) & $45.4(10.2)$ & $49.3(11.4)$ & .23 \\
\hline Disease duration (years), mean (SD) & $8.7(6.4)$ & $12.2(9.7)$ & .17 \\
\hline Disease course, $n(\%)$ & & & .40 \\
\hline Relapsing remitting & $16(76)$ & $13(54)$ & \\
\hline Secondary progressive & $4(19)$ & $7(29)$ & \\
\hline Primary progressive & $1(4)$ & $3(12)$ & \\
\hline Benign & $0(0)$ & $1(4)$ & \\
\hline Education, n (\%) & & & .39 \\
\hline Lower & $6(28)$ & $10(41)$ & \\
\hline Middle & $12(57)$ & $7(29)$ & \\
\hline Higher & $3(14)$ & $7(29)$ & \\
\hline Computer use, n (\%) & & & .83 \\
\hline Several times per day & $5(23)$ & $5(20)$ & \\
\hline Daily & $9(42)$ & $10(41)$ & \\
\hline Several times per week & $3(14)$ & $5(20)$ & \\
\hline Once per week & $0(0)$ & $1(4)$ & \\
\hline Rarely or never & $4(19)$ & $3(12)$ & \\
\hline Computer skills, n (\%) & & & .71 \\
\hline Rapidly familiar with new programs & $7(33)$ & $7(29)$ & \\
\hline Familiar after some log-ins & $8(38)$ & $11(46)$ & \\
\hline Difficulties with getting familiar & $5(24)$ & $6(25)$ & \\
\hline Impossible to get familiar & $1(5)$ & $0(0)$ & \\
\hline
\end{tabular}

\section{Data Analysis}

For all outcomes, the absolute values at baseline and follow-up are presented as mean, standard deviation (SD), minimum, and maximum. As the study's purpose was to investigate whether short-term changes could be observed after the start of MSmonitor usage, we compared in each group the follow-up with the baseline values by using multiple paired $t$ tests. The baseline characteristics in the MSmonitor and control groups were tested for differences using $t$ tests and $\chi^{2}$ tests. The analyses were performed at the Department for Health Evidence, Radboud University Medical Centre, Nijmegen, the Netherlands. For all tests, a $P$ value of $<.05$ was considered significant.

\section{Results}

\section{Patient Characteristics}

A total of 45 patients were included, 21 in the MSmonitor group and 24 in the control group. Demographics, characteristics of disease, level of education, degree of computer use, and degree of computed skills in both groups are presented in Table 3. There were no statistically significant differences with respect to gender, age, duration of disease, course of disease, level of education, degree of computer use, or degree of computer skills.

A total of 2 patients in the MSmonitor group and 1 in the control group failed to complete the follow-up questionnaires. Hence, the data analysis set comprised 19 MSmonitor and 23 control patients.

\section{MSmonitor Utilization}

At 1 month, all 19 patients had used the Quick Scan. As not all patients started usage immediately after baseline assessment, the second and third Quick Scans were available to 11 and 7 patients, respectively, and these were used by 9 and 7 of them, respectively. Accordingly, the Quick Scan utilization rate was $95 \%$ (35/37). The MSIP was used by 14 out of 19 patients, and the MSQoL-54 by 4 out of 5 patients to whom it was available. So, in total, the Quick Scan, MSIP, and MSQoL-54 were available 61 times and were used 53 times, resulting in a combined completion rate of $87 \%$ for these 3 components. The Activity Diary was used by $13(68 \%)$ patients; and in these, the mean (minimum, maximum) number of days of usage was 12 $(1,44)$. In all, the completion frequencies of Quick Scan, MSIP, and MSQoL-54, and the percentage of patients using the Activities Diary, resulted in an overall utilization rate of $83 \%$ of the MSmonitor components.

The Medication and Adherence Inventory part of the first Quick Scan showed that 10 of the 19 patients used a DMD and that 2 
patients had missed 1 and 2 doses, respectively, in the preceding month. Moreover, all patients completed the first Quick Scan, whereas patients who also used the Activity Diary completed the second Quick Scan more frequently than those who did not use the Activity Diary (8/11 vs $1 / 8)$.

\section{Empowerment Outcomes}

The mean, SD, minimum, and maximum values of the various outcome scores at baseline and at follow-up are presented in Table 4.
In the MSmonitor group, scores remained unchanged for MSSES control, MSSES function, IPA limitations, IPA problems, PIH coping, PIH recognition and management of symptoms, and PIH adherence to treatment. The mean PIH knowledge score decreased, suggesting an improvement. In the control group, all scores were unchanged.

Table 4. Mean (SD) and minimum-maximum values of Multiple Sclerosis Self-Efficacy Scale, Impact on Participation and Autonomy, and Partners In Health scores at baseline and at follow-up in the MSmonitor and control groups.

\begin{tabular}{|c|c|c|c|c|c|c|}
\hline \multirow[t]{2}{*}{ Empowerment aspects } & \multicolumn{3}{|l|}{ MSmonitor (n=19) } & \multicolumn{3}{|l|}{ Control $(n=23)$} \\
\hline & $\begin{array}{l}\text { Baseline, mean (SD); } \\
\text { minimum-maximum }\end{array}$ & $\begin{array}{l}4 \text { months, mean }(\mathrm{SD}) \text {; } \\
\text { minimum-maximum }\end{array}$ & $P$ value & $\begin{array}{l}\text { Baseline, mean }(\mathrm{SD}) \\
\text { minimum-maximum }\end{array}$ & $\begin{array}{l}4 \text { months, mean }(\mathrm{SD}) \\
\text { minimum-maximum }\end{array}$ & $P$ value \\
\hline MSSES $^{\mathrm{a}}$ control & $59.8(19.0), 20.0-87.8$ & $63.4(17.7), 32.2-94.4$ & .19 & $55.3(19.5), 25.6-96.7$ & $53.7(20.8), 22.2-91.1$ & .40 \\
\hline MSSES function & 72.4 (22.4), 28.9-100 & 73.5 (21.8), 30.0-100 & .62 & 67.8 (24.3), 21.3-100 & 66.5 (23.5), 26.7-100 & .17 \\
\hline IPA $^{\mathrm{b}}$ limitations & $2.8(0.4), 1.7-3.6$ & $2.7(0.6), 1.6-3.7$ & .26 & $2.6(0.7), 1.1-4.0$ & $2.6(0.6), 1.5-3.95$ & .28 \\
\hline IPA problems & $0.71(0.36), 0.00-1.71$ & $0.79(0.48), 0.00-1.86$ & .40 & $0.97(0.35), 0.22-1.71$ & 0.85 (0.35), $0.00-1.43$ & .25 \\
\hline $\mathrm{PIH}^{\mathrm{c}}$ coping & $19.2(3.3), 13.0-24.0$ & $18.9(4.8), 4.0-24.0$ & .73 & $18.6(3.9), 8.0-24.0$ & $18.9(3.2), 12.0-24$ & .76 \\
\hline PIH symptoms & $21.9(1.2), 20.0-24.0$ & $21.6(2.3), 16.0-24.0$ & .52 & $20.8(2.2), 16.0-24.0$ & 20.9 (2.6), $13.0-24$ & .87 \\
\hline PIH adherence & $15.1(1.4), 11.0-16.0$ & 14.9 (2.2), 8.0-16.0 & .80 & $14.8(1.4), 12.0-16.0$ & $14.6(2.3), 7.0-16$ & .34 \\
\hline PIH knowledge & $28.7(2.0), 25.0-32.0$ & $27.8(1.7), 24.0-30.0$ & .02 & $27.7(3.4), 21.0-31.0$ & $28.7(2.2), 24.0-32$ & .24 \\
\hline
\end{tabular}

${ }^{a}$ MSSES: Multiple Sclerosis Self-Efficacy Scale.

bIPA: Impact on Participation and Autonomy.

${ }^{\mathrm{c}}$ PIH: Partners In Health.

\section{Discussion}

\section{Principal Findings}

We conducted a quasi-experimental study in first-time users of MSmonitor to explore the program's early effects on empowerment and found that at 4 months' follow-up, self-efficacy, participation, autonomy, and self-management did not change, whereas knowledge had increased. The increase in the PIH knowledge score was about 0.9 SD baseline, which suggests that the change was clinically meaningful and can therefore be qualified as an improvement. It is, however, not sure to what degree the better knowledge results from the utilization of MSmonitor because at the time of the study, the program had not included an information function with links to websites of patient organizations and health care organizations.

In all, our findings suggest that early improvement of patient empowerment is unlikely to occur after starting MSmonitor. This result is clinically relevant as it may be communicated to first-time users to prevent them from having unrealistic expectations about the program's effects. Similarly, health care professionals should not expect their patients to have a better control of their situation, increased participation in care processes, or improved self-management in the short term $[3,8,9]$. A lack of utilization is unlikely to explain the unchanged empowerment outcomes, as the program's utilization was high; the overall rate being $83 \%$.

An additional finding was the association between the completion of the Quick Scan and the use of the Activity Diary. Although all patients completed the first Quick Scan, those who also used the Activity Diary evidently completed the second Quick Scan more frequently. This suggests a substantial relationship between repeated self-assessments of fatigue and HRQoL on the one hand and the documentation of activities and resting periods on the other hand and is in agreement with the hypothesis on the role of the program in self-management of fatigue. It may therefore be promising for future research on the effects of MSmonitor to focus on medium- to long-term changes in fatigue and on how patients self-manage their fatigue.

\section{Limitations}

The study has several limitations. First, the sample size, and therefore the chance of achieving statistically significant results, was rather low. Nevertheless, it may have been large enough to detect clinically relevant changes, as is suggested by the improved PIH knowledge score. Second, the study group was heterogeneous. Self-management perspectives and goals may differ between relapsing remitting, secondary progressive, and primary progressive patients. Moreover, the failure to detect a change in the PIH adherence to treatment score may relate to the fact that 9 of the 19 patients were not treated with a DMD, 
whereas only 2 of the DMD-treated patients reported (a low number of) missed doses [45]. Actually, the low incidence of DMD treatment in our patients may be explained by the fact that 1 out of 4 had progressive MS, and that in general 1 out of 4 patients with relapsing-remitting MS is not treated with a DMD [45]. Third, we included 5 patients in the MSmonitor group with reportedly low computer skills and 1 patient with reportedly no such skills, without offering them further training or education. This may have prevented these patients from optimally using the program. Moreover, owing to financial restrictions, the technology was introduced to patients and health care professionals in a single introductory session, without further staff training or education of patients; the absence of an optimal embedding in the daily life of patients and practices of health care providers may have negatively influenced the occurrence of short-term effects. Fourth, patient involvement in the developing process of MSmonitor consisted of receiving patient feedback on a continuous basis via the program's helpdesk and by means of meetings in the hospitals where the program was implemented. However, there were no cocreation sessions or focus group meetings, and this may be considered a limitation. Fifth, the study was not randomized. The fact that it was the participants who decided which group to join may have biased their reporting. As, however, both groups failed to show changes at follow-up (except for knowledge in the MSmonitor group), this limitation seems of minor importance. Finally, some aspects of empowerment were not covered by the questionnaires, such as support and patient-provider interaction $[46,47]$.

\section{Comparison With Prior Work}

Few studies have investigated the effect of Web-based self-management and care programs on empowerment in patients with MS, and the results are ambiguous. In a 6-month uncontrolled study $(\mathrm{n}=31)$ on the perceived benefits of Web-based MS-related patient-reported outcome collection, nearly $52 \%$ of the participants reported improved understanding of their disease [48]. Similarly, in a survey among MSmonitor users $(n=55), 46 \%$ reported that their insight into symptoms and disabilities had increased since the use of the program [24]. On the other hand, in a 12-month randomized controlled trial $(n=206)$, the expansion of an electronic MS health record with a self-monitoring and self-management system did not result in improved self-efficacy or symptoms [13]. Combined with the findings of this 4-month quasi-experimental study, the available data suggest that patient empowerment is not necessarily affected by the use of MS-related Web-based self-management and care programs.

Notably, self-management is a major issue for patients with MS. A recent study showed that positive expectations about the helpfulness for self-management is an important predictor for the acceptance of MS-related apps [49]. Actually, 26\% of the available MS-related apps have been designed for self-management purposes [50]. On the other hand, a recent review showed that the available MS apps fail to sufficiently meet the needs and demands of patients [51]. Although education and personal data management were the frequently included features, remote monitoring and fatigue management were often not present [51], despite the fact that fatigue management functions in mobile health solutions are important to patients with MS [52]. So, it seems that because of its fatigue management, monitoring and-recently added-information functions, MSmonitor compares favorably with the majority of MS apps [52].

The program's overall utilization rate was $83 \%$, whereas in a previous survey among all MSmonitor users, the most frequently used components Medication and Adherence Inventory, Activity Diary, and MSIP were used by $55 \%, 47 \%$, and $40 \%$ of the respondents, respectively [23]. It is known that long-term Web-based self-monitoring in patients with MS is hampered by a declining adherence, both in regular care and in direct-to-patient research settings [48,53]. Thus, in a 6-month study $(n=31)$ with monthly completion of 5 questionnaires, it was found that all questionnaires were completed less frequently in the second 3 months [48]. Interestingly, a recent study suggests that continuous communication with patients may promote the continued use of digital data collection tools [54]. Moreover, adaptation of digital self-monitoring tools to patients' personal situation, giving guidance to increase the value of their data, and integration of digital self-monitoring into treatment plans might also increase the adherence of patients with MS to Web-based programs and apps [55].

Finally, a recent review identified over 100 MS-related apps, but in none was evidence found in the literature on evaluation of the effects [50]. This may be worrisome, as the widespread implementation and utilization of MS-related Web-based programs, including mobile apps, will most likely depend on whether convincing evidence can be obtained regarding their effectiveness and cost-effectiveness [50]. Owing to limited resources, it is unlikely that all available tools will be evaluated in randomized controlled trials [56]. Moreover, the external validity of trial results is not self-evident, given that patient preferences may differ between regions or countries and preferences may change over time and the ongoing development of the tools. Therefore, prospective observational studies in real-world settings and retrospective studies using large databases are increasingly being considered as alternatives for obtaining actionable data $[56,57]$.

\section{Conclusions}

In a quasi-experimental study, we investigated short-term changes in empowerment in patients with MS who started using the Web-based program MSmonitor. At 4 months, self-efficacy, participation, autonomy, coping, recognition and management of symptoms, and adherence to treatment did not change. The utilization rate of the program's components was high. Our findings suggest that it may not be justified for first-time users of MSmonitor and their health care providers to expect a short-term improvement in empowerment. Immediate effects might be realized by better informing patients about the option to give the multidisciplinary team access to their data, as this may influence treatment decisions and care at short notice. It may well be that the program becomes effective in the medium to long term because of patients becoming increasingly familiar with the various components and their possibilities. A better adjustment of the program to the expectations and wishes of patients-in terms of content, personalization, and integration 
into treatment plans - is expected to also enhance empowerment

\section{Acknowledgments}

The authors thank Yvonne Kroon, Curavista bv, Geertuidenberg, the Netherlands, for providing the data on MSmonitor utilization. At the time of the study, the MSmonitor program was funded by Teva Netherlands, Curavista bv, and MS4 Research Institute, the Netherlands.

\section{Conflicts of Interest}

EN is co-owner of Curavista bv, Geertruidenberg, the Netherlands. PJ has received expense compensation from Curavista bv for serving as chairman of the board of the MSmonitor Foundation, and honoraria from Bayer Netherlands for consultancy activities.

\section{References}

1. Oh J, Vidal-Jordana A, Montalban X. Multiple sclerosis: clinical aspects. Curr Opin Neurol 2018 Dec;31(6):752-759. [doi: 10.1097/WCO.0000000000000622] [Medline: 30300239]

2. Dobson R, Giovannoni G. Multiple sclerosis - a review. Eur J Neurol 2019 Jan;26(1):27-40. [doi: 10.1111/ene.13819] [Medline: $\underline{30300457]}$

3. Lejbkowicz I, Caspi O, Miller A. Participatory medicine and patient empowerment towards personalized healthcare in multiple sclerosis. Expert Rev Neurother 2012 Mar;12(3):343-352. [doi: 10.1586/ern.11.161] [Medline: 22364333]

4. Rappaport J. Community psychology. In: Corsini R, editor. Encyclopedia of Psychology. New York: Wiley; 1984:252-254.

5. Anderson RM, Funnell MM. Patient empowerment: myths and misconceptions. Patient Educ Couns 2010 Jun;79(3):277-282 [FREE Full text] [doi: 10.1016/j.pec.2009.07.025] [Medline: 19682830]

6. Agner J, Braun KL. Patient empowerment: a critique of individualism and systematic review of patient perspectives. Patient Educ Couns 2018 Dec;101(12):2054-2064. [doi: 10.1016/j.pec.2018.07.026] [Medline: 30143254]

7. Risling T, Martinez J, Young J, Thorp-Froslie N. Defining empowerment and supporting engagement using patient views from the citizen health information portal: qualitative study. JMIR Med Inform 2018 Sep 10;6(3):e43 [FREE Full text] [doi: 10.2196/medinform.8828] [Medline: 30201603]

8. Castro EM, van Regenmortel T, Vanhaecht K, Sermeus W, van Hecke A. Patient empowerment, patient participation and patient-centeredness in hospital care: a concept analysis based on a literature review. Patient Educ Couns 2016 Dec;99(12):1923-1939. [doi: 10.1016/j.pec.2016.07.026] [Medline: 27450481]

9. McAllister M, Dunn G, Payne K, Davies L, Todd C. Patient empowerment: the need to consider it as a measurable patient-reported outcome for chronic conditions. BMC Health Serv Res 2012 Jun 13;12:157 [FREE Full text] [doi: 10.1186/1472-6963-12-157] [Medline: 22694747]

10. Huang T, Sung C, Wang W, Wang B. The effects of the empowerment education program in older adults with total hip replacement surgery. J Adv Nurs 2017 Aug;73(8):1848-1861. [doi: 10.1111/jan.13267] [Medline: 28122161]

11. Chang J, Savage SJ, Waldman DM. Estimating willingness to pay for online health services with discrete-choice experiments. Appl Health Econ Health Policy 2017 Aug;15(4):491-500. [doi: 10.1007/s40258-017-0316-z] [Medline: 28290107]

12. Lejbkowicz I, Paperna T, Stein N, Dishon S, Miller A. Internet usage by patients with multiple sclerosis: implications to participatory medicine and personalized healthcare. Mult Scler Int 2010;2010:640749 [FREE Full text] [doi: 10.1155/2010/640749] [Medline: 22096625]

13. Miller DM, Moore SM, Fox RJ, Atreja A, Fu AZ, Lee J, et al. Web-based self-management for patients with multiple sclerosis: a practical, randomized trial. Telemed J E Health 2011;17(1):5-13 [FREE Full text] [doi: 10.1089/tmj.2010.0133] [Medline: 21214498]

14. Lavorgna L, Russo A, de Stefano M, Lanzillo R, Esposito S, Moshtari F, et al. Health-related coping and social interaction in people with multiple sclerosis supported by a social network: pilot study with a new methodological approach. Interact J Med Res 2017 Jul 14;6(2):e10 [FREE Full text] [doi: 10.2196/ijmr.7402] [Medline: 28710056]

15. Lavorgna L, Brigo F, Moccia M, Leocani L, Lanzillo R, Clerico M, et al. e-Health and multiple sclerosis: an update. Mult Scler 2018 Nov;24(13):1657-1664. [doi: 10.1177/1352458518799629] [Medline: 30231004]

16. de Jong CC, Ros WJ, van Leeuwen M, Schrijvers G. How professionals share an e-care plan for the elderly in primary care: evaluating the use of an e-communication tool by different combinations of professionals. J Med Internet Res 2016 Nov 24;18(11):e304 [FREE Full text] [doi: 10.2196/jmir.6332] [Medline: 27884811]

17. Rai M, Vigod SN, Hensel JM. Barriers to office-based mental health care and interest in e-communication with providers: a survey study. JMIR Ment Health 2016 Aug 1;3(3):e35 [FREE Full text] [doi: 10.2196/mental.6068] [Medline: 27480108]

18. Yeh P, Hung S, Lee M, Chiou W, Lai C, Tsai W, et al. Implementing web-based ping-pong-type e-communication to enhance staff satisfaction, multidisciplinary cooperation, and clinical effectiveness: A SQUIRE-compliant quality-improving study. Medicine (Baltimore) 2016 Nov;95(44):e5236 [FREE Full text] [doi: 10.1097/MD.0000000000005236] [Medline: $\underline{27858876}$ ] 
19. Haase R, Schultheiss T, Kempcke R, Thomas K, Ziemssen T. Use and acceptance of electronic communication by patients with multiple sclerosis: a multicenter questionnaire study. J Med Internet Res 2012 Oct 15;14(5):e135 [FREE Full text] [doi: 10.2196/jmir.2133] [Medline: 23069209]

20. Driscoll M, Gurka D. Using the electronic medical record to enhance physician-nurse communication regarding patients' discharge status. Nurs Adm Q 2015;39(4):E31-E37. [doi: 10.1097/NAQ.0000000000000127] [Medline: 26340250]

21. O'Malley AS, Reschovsky JD, Saiontz-Martinez C. Interspecialty communication supported by health information technology associated with lower hospitalization rates for ambulatory care-sensitive conditions. J Am Board Fam Med 2015;28(3):404-417 [FREE Full text] [doi: 10.3122/jabfm.2015.03.130325] [Medline: 25957373]

22. Jongen PJ, Sanders E, Zwanikken C, Koeman J, Visser LH, Koopmans P, OPTIVIT study group. Adherence to monthly online self-assessments for short-term monitoring: a 1-year study in relapsing-remitting multiple sclerosis patients after start of disease modifying treatment. Patient Prefer Adherence 2013;7:293-300 [FREE Full text] [doi: 10.2147/PPA.S40173] [Medline: 23589682]

23. Jongen PJ, Sinnige LG, van Geel BM, Verheul F, Verhagen WI, van der Kruijk RA, et al. The interactive web-based program MSmonitor for self-management and multidisciplinary care in multiple sclerosis: concept, content, and pilot results. Patient Prefer Adherence 2015;9:1741-1750 [FREE Full text] [doi: 10.2147/PPA.S93783] [Medline: 26715841]

24. Jongen PJ, Sinnige LG, van Geel BM, Verheul F, Verhagen WI, van der Kruijk RA, et al. The interactive web-based program MSmonitor for self-management and multidisciplinary care in multiple sclerosis: utilization and valuation by patients. Patient Prefer Adherence 2016;10:243-250 [FREE Full text] [doi: 10.2147/PPA.S93786] [Medline: 27042018]

25. Fisk JD, Ritvo PG, Ross L, Haase DA, Marrie TJ, Schlech WF. Measuring the functional impact of fatigue: initial validation of the fatigue impact scale. Clin Infect Dis 1994 Jan;18(Suppl 1):S79-S83. [doi: 10.1093/clinids/18.supplement 1.s79] [Medline: $\underline{8148458]}$

26. National MS Society. Multiple Sclerosis Quality of Life Inventory: A User's Manual URL: http://walkcoc. nationalmssociety.org/docs/HOM/MSQLI Manual and Forms.pdf [accessed 2020-01-07]

27. Ford HL, Gerry E, Tennant A, Whalley D, Haigh R, Johnson MH. Developing a disease-specific quality of life measure for people with multiple sclerosis. Clin Rehabil 2001 Jun;15(3):247-258. [doi: 10.1191/026921501673658108] [Medline: 11386394]

28. Ensari I, Motl RW, McAuley E. Structural and construct validity of the Leeds Multiple Sclerosis Quality of Life scale. Qual Life Res 2016 Jun;25(6):1605-1611. [doi: 10.1007/s11136-015-1202-5] [Medline: 26660145]

29. Zigmond AS, Snaith RP. The hospital anxiety and depression scale. Acta Psychiatr Scand 1983 Jun;67(6):361-370. [doi: $\underline{10.1111 / j .1600-0447.1983 . t b 09716 . x}$ ] [Medline: $\underline{6880820}$ ]

30. Honarmand K, Feinstein A. Validation of the Hospital Anxiety and Depression Scale for use with multiple sclerosis patients. Mult Scler 2009 Dec;15(12):1518-1524. [doi: 10.1177/1352458509347150] [Medline: 19965520]

31. Watson TM, Ford E, Worthington E, Lincoln NB. Validation of mood measures for people with multiple sclerosis. Int J MS Care 2014;16(2):105-109 [FREE Full text] [doi: 10.7224/1537-2073.2013-013] [Medline: 25061435]

32. Wynia K, Middel B, van Dijk JP, de Ruiter H, de Keyser J, Reijneveld SA. The Multiple Sclerosis impact Profile (MSIP). Development and testing psychometric properties of an ICF-based health measure. Disabil Rehabil 2008;30(4):261-274. [doi: 10.1080/09638280701256868] [Medline: 17852244$]$

33. Wynia K, Middel B, de Ruiter H, van Dijk JP, de Keyser JH, Reijneveld SA. Stability and relative validity of the Multiple Sclerosis Impact Profile (MSIP). Disabil Rehabil 2008;30(14):1027-1038. [doi: 10.1080/09638280701476193] [Medline: 18953748]

34. Vickrey BG, Hays RD, Harooni R, Myers LW, Ellison GW. A health-related quality of life measure for multiple sclerosis. Qual Life Res 1995 Jun;4(3):187-206. [doi: 10.1007/bf02260859] [Medline: 7613530 ]

35. University of Minnesota Twin Cities. 2018 Jun 25. Research Brief: Today's kids able to delay gratification longer than those in 1960s URL: https://twin-cities.umn.edu/news-events/research-brief-todays-kids-able-delay-gratificationlonger-those-1960s [accessed 2020-01-07]

36. Carlson SM, Shoda Y, Ayduk O, Aber L, Schaefer C, Sethi A, et al. Cohort effects in children's delay of gratification. Dev Psychol 2018 Aug;54(8):1395-1407. [doi: 10.1037/dev0000533] [Medline: 29939038]

37. Schwartz CE, Coulthard-Morris L, Zeng Q, Retzlaff P. Measuring self-efficacy in people with multiple sclerosis: a validation study. Arch Phys Med Rehabil 1996 Apr;77(4):394-398. [doi: 10.1016/s0003-9993(96)90091-x] [Medline: $\underline{\text { 8607766] }}$

38. Vazirinejad R, Lilley JM, Ward CD. The 'Impact on Participation and Autonomy': acceptability of the English version in a multiple sclerosis outpatient setting. Mult Scler 2003 Dec;9(6):612-615. [doi: 10.1191/1352458503ms936oa] [Medline: 14664475]

39. Karhula ME, Salminen A, Hämäläinen PI, Ruutiainen J, Era P, Tolvanen A. Psychometric evaluation of the Finnish version of the impact on participation and autonomy questionnaire in persons with multiple sclerosis. Scand J Occup Ther 2017 Nov;24(6):410-420. [doi: 10.1080/11038128.2016.1272630] [Medline: 28049364]

40. Petkov J, Harvey P, Battersby M. The internal consistency and construct validity of the partners in health scale: validation of a patient rated chronic condition self-management measure. Qual Life Res 2010 Sep;19(7):1079-1085. [doi:

10.1007/s11136-010-9661-1] [Medline: 20437206] 
41. Lenferink A, Effing T, Harvey P, Battersby M, Frith P, van Beurden W, et al. Construct validity of the Dutch version of the 12-item Partners in Health Scale: measuring patient self-management behaviour and knowledge in patients with chronic obstructive pulmonary disease. PLoS One 2016;11(8):e0161595 [FREE Full text] [doi: 10.1371/journal.pone.0161595] [Medline: 27564410]

42. Cardol M, de Haan RJ, de Jong BA, van den Bos GA, de Groot IJ. Psychometric properties of the Impact on Participation and Autonomy Questionnaire. Arch Phys Med Rehabil 2001 Feb;82(2):210-216. [doi: 10.1053/apmr.2001.18218] [Medline: 11239312]

43. Cardol M, Beelen A, van den Bos GA, de Jong BA, de Groot IJ, de Haan RJ. Responsiveness of the Impact on Participation and Autonomy questionnaire. Arch Phys Med Rehabil 2002 Nov;83(11):1524-1529. [doi: 10.1053/apmr.2002.35099] [Medline: 12422319]

44. Franchignoni F, Ferriero G, Giordano A, Guglielmi V, Picco D. Rasch psychometric validation of the Impact on Participation and Autonomy questionnaire in people with Parkinson's disease. Eura Medicophys 2007 Dec;43(4):451-461 [REEE Full text] [Medline: 18084167$]$

45. Minden SL, Kinkel RP, Machado HT, Levin JS, Rosenthal MB, Iezzoni LI. Use and cost of disease-modifying therapies by Sonya Slifka Study participants: has anything really changed since 2000 and 2009? Mult Scler J Exp Transl Clin 2019;5(1):2055217318820888 [FREE Full text] [doi: 10.1177/2055217318820888] [Medline: 30815276]

46. Chiauzzi E, DasMahapatra P, Cochin E, Bunce M, Khoury R, Dave P. Factors in patient empowerment: a survey of an online patient research network. Patient 2016 Dec;9(6):511-523 [FREE Full text] [doi: 10.1007/s40271-016-0171-2] [Medline: 27155887]

47. Kantor D, Bright JR, Burtchell J. Perspectives from the patient and the healthcare professional in multiple sclerosis: social media and participatory medicine. Neurol Ther 2018 Jun;7(1):37-49 [FREE Full text] [doi: 10.1007/s40120-017-0088-2] [Medline: 29222700]

48. Engelhard MM, Patek SD, Sheridan K, Lach JC, Goldman MD. Remotely engaged: lessons from remote monitoring in multiple sclerosis. Int J Med Inform 2017 Apr;100:26-31 [FREE Full text] [doi: 10.1016/j.ijmedinf.2017.01.006] [Medline: 28241935]

49. Apolinário-Hagen J, Menzel M, Hennemann S, Salewski C. Acceptance of mobile health apps for disease management among people with multiple sclerosis: web-based survey study. JMIR Form Res 2018 Dec 12;2(2):e11977 [FREE Full text] [doi: 10.2196/11977] [Medline: 30684408]

50. Salimzadeh Z, Damanabi S, Kalankesh LR, Ferdousi R. Mobile applications for multiple sclerosis: a focus on self-management. Acta Inform Med 2019 Mar;27(1):12-18 [FREE Full text] [doi: 10.5455/aim.2019.27.12-18] [Medline: 31213737]

51. Giunti G, Fernández EG, Zubiete ED, Romero OR. Supply and demand in mHealth apps for persons with multiple sclerosis: systematic search in app stores and scoping literature review. JMIR Mhealth Uhealth 2018 May 23;6(5):e10512 [FREE Full text] [doi: 10.2196/10512] [Medline: 29792295]

52. Giunti G, Kool J, Romero OR, Zubiete ED. Exploring the specific needs of persons with multiple sclerosis for mHealth solutions for physical activity: mixed-methods study. JMIR Mhealth Uhealth 2018 Feb 9;6(2):e37 [FREE Full text] [doi: 10.2196/mhealth.8996] [Medline: 29426814]

53. Jongen PJ, Kremer IE, Hristodorova E, Evers SM, Kool A, van Noort EM, et al. Adherence to web-based self-assessments in long-term direct-to-patient research: two-year study of multiple sclerosis patients. J Med Internet Res 2017 Jul 21;19(7):e249 [FREE Full text] [doi: 10.2196/jmir.6729] [Medline: 28733272]

54. Karnoe A, Kayser L, Skovgaard L. Identification of factors that motivate people with multiple sclerosis to participate in digital data collection in research: sequential mixed methods study. JMIR Hum Factors 2019 Oct 9;6(4):e13295 [FREE Full text] [doi: 10.2196/13295] [Medline: 31599738]

55. Wendrich K, van Oirschot P, Martens MB, Heerings M, Jongen PJ, Krabbenborg L. Toward digital self-monitoring of multiple sclerosis: investigating first experiences, needs, and wishes of people with ms. Int J MS Care 2019;21(6):282-291 [FREE Full text] [doi: 10.7224/1537-2073.2018-083] [Medline: 31889935]

56. Marziniak M, Brichetto G, Feys P, Meyding-Lamadé U, Vernon K, Meuth SG. The use of digital and remote communication technologies as a tool for multiple sclerosis management: narrative review. JMIR Rehabil Assist Technol 2018 Apr 24;5(1):e5 [FREE Full text] [doi: 10.2196/rehab.7805] [Medline: 29691208]

57. Jongen PJ. Observational designs in clinical multiple sclerosis research: particulars, practices and potentialities. Mult Scler Relat Disord 2019 Oct;35:142-149. [doi: 10.1016/j.msard.2019.07.006] [Medline: 31394404]

\section{Abbreviations}

DMD: disease-modifying drug

HADS: Hospital Anxiety and Depression Scale

HRQoL: health-related quality of life

IPA: Impact on Participation and Autonomy

LMSQoL: Leeds Multiple Sclerosis Quality of Life 
MFIS-5: Modified Fatigue Impact Scale-5 items

MS: multiple sclerosis

MSIP: Multiple Sclerosis Impact Profile

MSQoL-54: Multiple Sclerosis Quality of Life-54

MSSES: Multiple Sclerosis Self-Efficacy Scale

PIH: Partners In Health

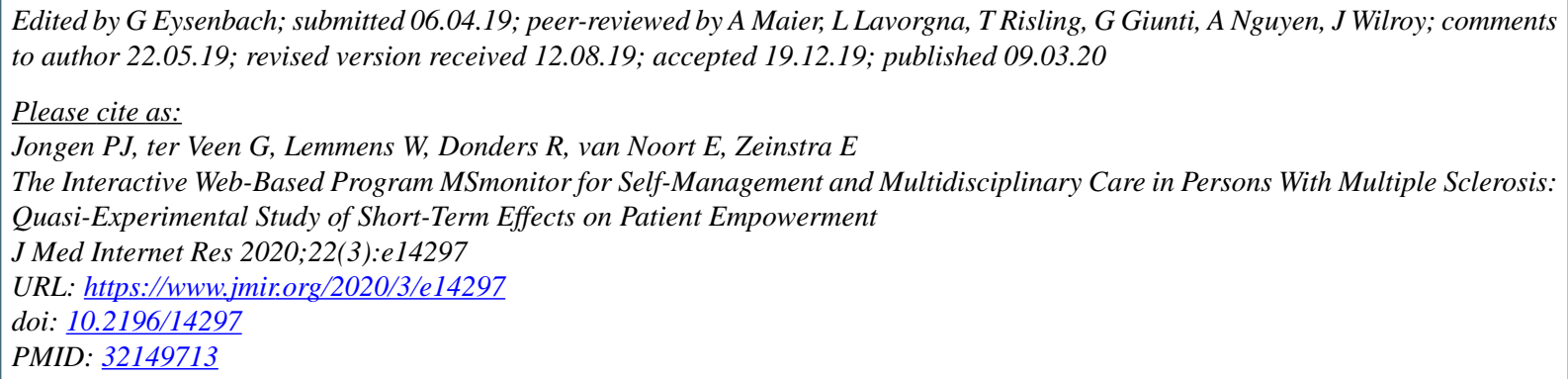

(CPeter Joseph Joseph Jongen, Gezien ter Veen, Wim Lemmens, Rogier Donders, Esther van Noort, Esther Zeinstra. Originally published in the Journal of Medical Internet Research (http://www.jmir.org), 09.03.2020. This is an open-access article distributed under the terms of the Creative Commons Attribution License (https://creativecommons.org/licenses/by/4.0/), which permits unrestricted use, distribution, and reproduction in any medium, provided the original work, first published in the Journal of Medical Internet Research, is properly cited. The complete bibliographic information, a link to the original publication on http://www.jmir.org/, as well as this copyright and license information must be included. 